УДК 165.74

АНДРІЙ ОСІПЦОВ

доктор педагогічних наук, професор завідувач кафедри фізичного виховання, спорту та здоров'я людини, Маріупольський державний університет (м. Маріуполь, Украӥна) e-mail: a.osiptsov@mdu.in.ua,ORCID 0000-0002-1640-2632

ОЛЬГА ЦИБУЛЬКО кандидат історичних наук, дочент кафедри філософії та соиіології, Маріупольський державний університет (м. Маріуполь, Україна) e-mail: ostsybulco@ukr.net,ORCID 0000-0003-1297-5465

НАТАЛІЯ САЛЬНІКОВА кандидат історичних наук, завідувач кафедри гуманітарних дисциплін. Донеиький юридичний інститут МВС України (м. Маріуполь, Украӥна) ORCID 0000-0003-4931-0491

\title{
ПРОБЛЕМА РОЗВИТКУ ОСВІТНІХ ПЕРЕКОНАНЬ У ФІЛОСОФСЬКІЙ ТРАДИЩЇ̈ ЧАРЛЬЗА ПІРСА
}

У статті досліджується проблема розвитку освітніх переконань у філософській традиції Чарльза Пірса. Пірс підтримує позицію, яка вимагає систематичного дослідження та фундаментальної відкритості новим ідеям. Це вимагає посередництва між дисциплінованими індукцією і дедукцією, з одного боку, і естетично споглядальної, інтуїтивної та вільної гри 3 ідеями, з іншого, оскільки зрозумілі переконання набувають певної форми та розвиваються в рамках динамічної взаємодії між безперервним і уривчастими процесами в науковому колективі. Якщо ми хочемо застосувати погляди Пірса до соціальної побудови освітніх переконань, то ми одразу ж виявимо, що наші вірування не відокремлені від фактично заснованих на нормах освіти і взаємодіють 3 ними. Пірс сприяє розумінню освітніх переконань як «живої історичної істоти» та «здорового глузду». Проте, оскільки освітні переконання опосередковані, соціально орієнтовані і орієнтовані на майбутнє, ми не можемо судити про освітні переконання грунтуючись на попередніх висновках. Оскільки освітні переконання обов'язково є попередніми і не остаточними. Освітні переконання і судження повинні оцінюватися відповідно до легітимності норм, що скеровують дослідження, тобто норм, що направляють освітні дослідження, побудове теорії і практику. Таким чином, приймаючи точку зору Пірса, дослідження в галузі освіти, побудова теорії і практики повинні характеризуватися як взаємодія загальних процесів спільного навчання. При цьому метод дослідження Пірса - як етос освітнього дослідження, побудови теорії і практики може бути корисний для відмінності догматизму від прагматизму.

Ключові слова: прагматизм; освітні переконання; освіта; значення; практика

Постановка завдання та аналіз останніх публікацій. Сучасна українська освітня система не позбавлена певних проблем та недоліків. Особливо актуальним на сьогодні $\epsilon$ розуміння сутності такого явища як «освітній процес». В цьому контексті логічним $є$ спроба аналізу філософської спадщини видатного прагматиста Чарльза Пірса. Для аналізу такого явища як «освіта» та «освітні переконання» слугували власне роботи Ч. Пірса (Peirce C.S, 1867-1893, 1893-1913), загальні праці з філософії прагматизму (Schurz G., 1998, Жарких В. Ю., 2009), а також дослідження Жирара Діледея присвячене власне аналізу ідей Пipca (Deledalle G., 2000). 
Разом з тим, саме дослідженню проблеми розвитку освітніх переконань у філософській традиції Чарльза Пірса приділено мало уваги.

Мета цього дослідження - дослідження проблеми розвитку освітніх переконань у філософській традиції Чарльза Пірса.

Виклад основного матеріалу. Вивчення філософіï Чарльза Сандерса Пipca $\epsilon$ важливим кроком для належного усвідомлення його освітніх переконань.

Пірсовим визначенням знання є дієслово, опосередковане символами, що грунтуються на практичних міркуваннях, підтверджені прагматичним принципом і остаточним консенсусом. Суть знання за Пірсом полягає у процесах конструювання, реконструкції та підтвердженні думок.

Пірс просуває свій «метод наукових досліджень» як науковий етос. Грунтуючись на шести логічних есе Пірса, опублікованих в «Рopular Science Monthly», можна стверджувати, що метод Пірса 6 протилежністю індивідуального і апріорного способу мислення (Peirce C.S., 1992, с. 167).

Пірс вважає, що науковий метод є продуктивним завдяки нормам, які скеровують дослідження: прагматичний принцип, соціальний принцип, тобто творчі і новаторські висновки.

В есе «Питання, що стосуються певних здібностей, потрібних людині», Пірс зазначає, що наші переконання грунтуються на більш ранніх переконаннях (Peirce C.S., 1992, c. 181).

Пірс описує пізнання як реляційний і еволюційний феномен, що також $є$ продуктом нашого мислення, тобто наші переконання, без сумніву, слід розуміти як реляційний і еволюційний чинник.

У другому епістемологічному есе «Деякі наслідки чотирьох недієздатностей» Пірс розширює цю аргументацію, стверджуючи, що саме мислення повністю позбавлене цінності (Peirce C.S., 1992, с. 234).

Отже, освітні переконання слід розуміти як реляційні, еволюційні, бо переконання безперервно взаємодіють 3 іншими ідеями, оскільки вони вписані в особисту й інтелектуальну біографію педагога.

Освітні переконання соціально зорієнтовані, тобто освітні переконання $є$ невід'ємною частиною соціально обгрунтованих дискурсів. Це те, що Пірс розглядає, коли стверджує, що «соціальний принцип постає 3 логіки». Цей «соціальний принцип» пов’язаний з поняттям Пірса про кінцевий консенсус i причинами цього $є$ характеристика наукової логіки як «критичного здорового глузду».

Відповідно до поглядів Пірса, остаточний консенсус, або «остаточну думку», слід розглядати як регулюючий ідеал для наукової практики, оскільки істина - це те, чого досягне необмежена кількість людей, якщо вона буде постійно досліджувати цю гіпотезу.

Тому причиною, за якою Пірс відкинув суб’єктивний критерій для доказів, заснована на відмові від упередженого субстанціалізму та історичного факту, що вперті люди часто дотримуються помилкових переконань, і того факту, що подібні знання, можуть бути пов’язані з апріорною концепцією. Навпаки, Пірс 
стверджує, що знання слід розглядати як соціально налаштоване, апостеріорне явище.

А тому, Пірс пояснює, як освітні вірування зорієнтовані на майбутнє, оскільки вони безперервно конструюються, реконструюються і стають традиційними у зв'язку з роздумами про цілі і масштаби освітніх процесів (Schurz G., 1998, c. 45).

Тобто, наші переконання грунтуються і підтверджуються практичними міркуваннями, пов’язаними з освітніми процесами, в тому сенсі, що наші переконання є принципами, за якими ми готові жити. У цьому контексті освітні переконання набувають значення в залежності від очікувань, тобто який внесок вони можуть зробити в розвиток освітнього проекту.

Отже, освітні переконання не тільки засновані на колишніх переконаннях, але також можуть бути охарактеризовані як орієнтовані на майбутні «принципи надії». А Пірс наголошує, як освітні переконання вбудовуються в суспільне створення сенсу.

На думку Пірса, освітні переконання необхідно розглядати в межах термінів «значення», а не «знання». Для нього значення пов’язане 3 очікуваними наслідками наших переконань, в яких знак є сутністю. Віра - це певний знак, і якщо вона повинна мати значення, то іiі слід інтерпретувати як знак, пов’язаний з об'єктом, або іншим знаком. Неінтерпретований знак не має сенсу (Жарких В. Ю., 2009, с. 125). Таким чином, значення - це реляційна сутність, в якій позиція інтерпретує суб'єкта та усталені переконання. Для Пірса значення - це зв'язок між трьома компонентами: знаком, інтерпретацією і об'єктом.

Філософія Пірса може поліпшити суспільне розуміння освітніх переконань як опосередкованих, соціально орієнтованих і прогресивних думок. Оскільки, по-перше, наші переконання формуються у постійній взаємодії з попереднім досвідом і переконаннями, по-друге, освітні ініціативи є частиною соціально обгрунтованого дискурсу, по-третє, освітні переконання постійно утворюються, реконструюються і підтверджуються відповідно до вимог освітнього процесу.

Таким чином, Пірс зробив свій внесок у вивчення проблеми розвитку освітніх переконань у контексті конкретного освітнього проекту. Логіка Пірса сприяє встановленню того, як освітні переконання стають невід'ємною частиною світових інтерпретацій. Таким чином, прагматизм Пірса доводить, що освітні переконання є невід'ємною частиною процесів, які об'єднують минуле, сьогодення i майбутнє за допомогою аналізу, проблематики та практики освітніх питань.

Не $є$ доречним поставити під сумнів той факт, що освітні переконання конструюються, бо, у цьому випадку, освітній проект може виявитися догматичним.

Для Пірса сумнів i віра $\epsilon$ двома прагматичними, взаємозалежними елементами у контексті розвитку знання. Тому сумнів не є негативним явищем. А навпаки, сумнів є позитивним аспектом людського мислення, оскільки він мотивує людину до аналізу, а відповідно до навчання. 
Однак, аргументація Пірса спростувала Декартовий погляд на сумнів. Коли Декарт сформулював крилату фразу: «соgito, ergo sum», «я думаю, тому я існую», він вважав, що досяг абсолютної впевненості, тому що, пройшовши довгий ланцюг думок, він дійшов висновку, що єдине у чому він не міг сумніватися, так це в тому, що він сумнівався (Жарких В. Ю., 2009). Для Пірса ж сумнів Декарта $є$ раціоналізованою пародією на справжній сумнів, оскільки він грунтувався на думках, повністю відірваних від життєвого досвіду. Отже, Декарт не міг випробувати справжнього сумніву, а лише визнав можливість сумніву. Пірс стверджує, що справжній сумнів завжди пов'язаний з живим досвідом суб'єкта. Крім того, сумнів не може бути універсальним. Неможливо сумніватися в кожному постулаті віри одночасно, бо це унеможливить відокремлення віри від сумніву, що, в свою чергу, знищить і віру, і сумнів як реальне явище.

В есе «Закріплення вірування», Пірс аналізує зв'язок між сумнівом, вірою та звичкою (Пирс Ч.С., 1996, с. 113). Слово звичка, у цьому контексті, він використовує як звичне мислення і дію. Звичні дії є результатами людських переконань і способами їх підтримки. Збережені переконання спрямовують нашу увагу на характеристики певних явищ i, таким чином, зменшують роздратування сумнівами.

Таким чином, наші переконання впливають на встановлення певних форм звичних дій, а тому можуть сприяти зміцненню переконань. Навпаки, якщо невизначеність і сумніви породжують чинники роздратування людської свідомості, яких людина прагнула б уникнути, сумнів стає мотивацією для більш ретельного вивчення проблеми, тим самим зменшуючи роздратування сумнівом або змушуючи його зникнути. Усталені вірування ніколи не призведуть до подібної мотивації. Навпаки, усталені переконання можуть вплинути на те, що питання будуть залишені без суттєвого розгляду.

У своїх інших працях Пірс зображує поняття вірувань як цілісну структуру. Тобто, звички і переконання складаються і підтримуються з плином часу, вони несвідомі і певним чином здатні до самозбереження. Однак, Пірс розглядає віру та звичку як в психологічному, так і в онтологічному контексті, оскільки звичка не може бути зведена до мислення або дії, а повинна сприйматися як набір внутрішніх, об'єктивних диспозицій, що відображаються в певних закономірностях, думках і діях. А тому, сумнів також необхідно розглядати як психологічне та онтологічне явище. Психологічно сумнів дає суб'єктивне відчуття невпевненості. Онтологічно, а тому епістемологічно сумнів стає помилковою позицією, аномалією, непослідовною низкою аргументів.

Якщо активно залучати сумніви у галузі освіти, необхідно зрозуміти, чи пов'язані наші сумніви 3 відчуттям того, що деякі поширені освітні переконання є марними та безглуздими.

Пірс визначає чотири способи встановлення віри: метод завзятості, метод авторитету, філософський метод апріорі і науковий метод. Пірс дотримується свого наукового методу, керуючись «соціальним імпульсом», як єдиним 
способом встановлення правильних переконань. Це пов’язано з тим, що методи завзятості, авторитету і апріорі не включають керівних принципів мислення i, тому, можуть сприяти підтримці справжніх і помилкових переконань. Метод завзятості - або метод страуса - описує, як люди схильні сховати голови в пісок, як страуси. Метод авторитетності - охарактеризує те, як індивід дозволяє суспільству або владі визначати, що є правильним, а що ні, що істинним, а що хибним. Пірс визначає цей метод як «шлях до миру», тому що «мирній i співчуваючій людині буде важко встояти перед спокусою представити свої думки владі». Філософський метод, однак, розглядає нашу тенденцію сприймати традиційні апріорі лише тому, що вони нам подобаються, або тому що аргументи здаються переконливими. Прикладом є раціональний Декартовий доказ Бога, метафізика Канта і діалектика Гегеля, оскільки Пірс вказує на очевидні обмеження цих позицій. По-перше, доказ Бога Декартом є круговим, редукціоністським і суб'єктивістським, оскільки Бог є таким, яким ми його уявляємо. По-друге, метафізичний універсалізм Канта випускає з уваги контекстуальний, апостеріорний характер «наукових істин». По-третє, діалектика Гегеля, відповідно до поглядів Пірса, є інтелектуальним методом, що сприяє відверненню уваги від конкретного життєвого досвіду (Рeirce C.S., 1998, с. 427). Таким чином, Пірс вважає, що традиційна філософія може сприяти встановленню і збереженню нестабільних переконань.

На думку, Пірса, прогресивний науковий метод є єдиним методом, що відрізняє істинні та помилкові висновки. Цей метод є єдиним способом вирішити справжні сумніви, оскільки він керується деякою зовнішньої сталістю. Тобто, Пірс не оцінює метод за окремим висновком, до якого він призводить, або за попередніми знаннями, які він може дати. Навпаки, Пірс вважає, що цей метод є продуктивним, завдяки «керівному принципу», тобто нормам, що визначають запити.

Тобто, за умови використання наукового методу, необмеженої кількості раз, під час вивчення певного явища, упродовж необмеженого періоду часу, люди дійдуть до одного висновку. Це вказує на те, що науковий метод Пірса характеризується введеними ним нормами, які сформульовані як: прагматичний принцип, соціальний принцип, принцип Fallibilism і наукова творчість.

Прагматичний принцип грунтується на уявленні про те, що людські переконання підтверджуються очікуваними наслідками дій, 3 яких вони випливають. Однак, прагматичний принцип не варто інтерпретувати як деяку форму біхевіоризму, тобто просто очікування очікуваних наслідків конкретних дій людини. Навпаки, сам Пірс застосовує цей принцип до свого аналізу ознак.

Вільям Джеймс у свої лекції «Філософські концепції і практичні результати», назвав Пірса «батьком прагматизму». Однак, Джеймс дав новий імпульс розвитку прагматичним ідеям Пірса: оскільки він наголошував на зверненні до наслідків або поведінки конкретних артефактів та інтерпретував їх як «принцип практизму» (Deledalle G. 2000, с. 68). 
Тобто, прагматичний принцип - це пропозиція для досягнення ясності. Однак, оскільки наші переконання «можуть бути досить чіткими, не будучи істинними», прагматичний принцип недостатній.

Соціальний принцип, $€$ джерелом ідей про кінцевий консенсус як регулюючий ідеал. Оскільки. по-перше, Пірс передбачає, що зовнішня реальність безпосердньо впливає на наше мислення. По-друге, наш індивідуальний досвід i переконання про зовнішній світ завжди відрізнятимуться через індивідуальні чуттєві переживання. У другому логічному есе «Як прояснити наші ідеї», Пірс наводить такий приклад- це способи, якими маленька дитина, коли рухається, повзає, стрибає, бігає, танцює і грає, паралельно сприймає зовнішній світ. (Пирс Ч.С.,1996, с. 127).

Таким чином, емоційні переживання дитини сприяють закріпленню іiі уявлень або знань про світ. Проте, іiі переконання про світ під час пізнання кардинально відрізняються від реальності, в якій вона рухається.

Також, у кожної дитини будуть різні емоційні переживання - i, отже, вони отримають різні уявлення про світ. Отже, кожна людина здобуває різні переконання, засновані на життєвому досвіді зовнішньої реальності. Таким чином, ми не можемо залежати від своїх переконань як безпосереднього доступу до світу. Наші переконання - це певні інструменти, за допомогою яких ми розуміємо світ. Саме тому люди повинні знати, що для того щоб зробити наші переконання продуктивними, вони повинні бути створені в соціальному контексті, де переконання кожного індивіда доповнюють та коригують один одного. Чим більше людей залучено до цього суспільного процесу інтерпретацій, тим більша ймовірність прийти до розумної інтерпретацій. А тому, якщо ми не можемо довіряти нашим особистим переконанням, ми повинні соціально їх перевіряти. Таким чином, «соціальний принцип» $\epsilon$ «ідеальною досконалістю знань».

3 огляду на те, що наші висновки, переконання i припущення, $є$ не остаточними, ми повинні бути готові розробити метод, який допоможе відкоригувати наші переконання. Тому, Пірс вводить відмінність як норму, яка спрямовує науковий запит. Для Пірса Fallibilism - науковий етос, скромний погляд на ступінь, в якій наукова практика може сприяти більш глибокому розумінню досліджуваного явища. (Deledalle G. 2000, с. 112).

Через помилковий характер переконань і наукових положень, необхідно відвернути увагу від самих переконань і висловлювань і сконцентруватися на обгрунтованні вивідної процедури, за допомогою якої вони досягаються. Таким чином, дотримуючись фаллібілізму як керівного принципу, ми уникаємо надмірної віри в нашу наукову діяльність і iї результати, оскільки увага звертається на достовірність нашого мислення.

Також, Пірс звертає увагу на умовивід як до дійсної і цінної форми логічного висновку. Оскільки умовивід - єдиний спосіб міркування, який може створити нову гіпотезу - сприяє творчому мисленню. Дедукція доводить, що щось повинно бути; індукція показує, що щось дійсно є; умовивід вказує на те, що щось може відбутися. 
Таким чином, дедукція, як форма логічного висновку, може сприяти розголошенню чи з'ясування вже встановлених переконань. Використовуючи індуктивний висновок, можна було б, з іншого боку, перевірити гіпотезу i переглянути висновки. Однак, на відміну від індуктивного і дедуктивного мислення, абдуктивний висновок $є$ інноваційним. Тому тільки умовивід дозволяє висунути нову гіпотезу. Умовивід - це процес формування пояснювальної гіпотези. Це єдина логічна операція, яка вводить будь-яку нову ідею; оскільки індукція не робить нічого, крім визначення цінності, а дедукція розвиває необхідні наслідки чистої гіпотези.

Отже, Пірс підкреслює необхідність уривчастої, руйнівної логіки. Це свого роду розрив, який ми можемо назвати «відкритістю для нових ідей», «інтуїтивним розумінням», «здатністю робити якісні припущення» або просто «творчістю». Умовивід заохочує нас до естетичного аналізу, міркування i вільної гри з ідеями.

Фаллібілізм Пірса став підгрунтям до висунутої Поппером тези про те, що наші переконання повинні бути дійсними та повинні бути переглянутими. Але $\epsilon$ вирішальна відмінність між Пірсом і Поппером, в якій Поппер з його критерієм демаркації відмежовує логіку від естетики та етики, в той час коли Пірс, 3 іншого боку, їх об'єднує, вважаючи естетику summum bonum. (Schurz G., 1998, c. 47).

Висновки. У цілому, Пірс підтримує позицію, яка вимагає систематичного дослідження та фундаментальної відкритості новим ідеям. Це вимагає посередництва між дисциплінованими індукцією і дедукцією, з одного боку, i естетично споглядальної, інтуїтивної та вільної гри з ідеями, з іншого, оскільки зрозумілі переконання набувають певної форми та розвиваються в рамках динамічної взаємодії між безперервним і уривчастими процесами в науковому колективі.

Якщо ми хочемо застосувати погляди Пірса до соціальної побудови освітніх переконань, то ми одразу ж виявимо, що наші вірування не відокремлені від фактично заснованих на нормах освіти і взаємодіють з ними. Пірс сприяє розумінню освітніх переконань як «живої історичної істоти» та «здорового глузду».

Проте, оскільки освітні переконання опосередковані, соціально орієнтовані і орієнтовані на майбутне, ми не можемо судити про освітні переконання грунтуючись на попередніх висновках. Оскільки освітні переконання обов'язково $є$ попередніми і не остаточними. Освітні переконання і судження повинні оцінюватися відповідно до легітимності норм, що скеровують дослідження, тобто норм, що направляють освітні дослідження, побудове теорії і практику.

Таким чином, приймаючи точку зору Пірса, дослідження в галузі освіти, побудова теорії і практики повинні характеризуватися як взаємодія загальних процесів спільного навчання. При цьому метод дослідження Пірса - як етос освітнього дослідження, побудови теорії і практики - може бути корисний для відмінності догматизму від прагматизму. 


\section{СПИСОК ВИКОРИСТАНИХ ДЖЕРЕЛ}

Deledalle G. Charles Peirce's Philosophy of Signs: Essays in Comparative Semiotics, Bloomington: Indiana University Press, 2000. 372 p.

Peirce C.S. The Essential Peirce: Selected Philosophical Writings, vol. 1 (1867-1893), ed. N. Houser and C. Kloesel, Bloomington: Indiana University Press, 1992. 567

Peirce C.S. The Essential Peirce: Selected Philosophical Writings, vol 2 (1893-1913), ed. the Peirce Edition Project, Bloomington: Indiana University Press, 1998. 621

Schurz G. Kinds of Pragmatisms and Pragmatic Components of Knowledge. The Role of Pragmatics in Contemporary Philosophy. Vienna, 1998. P. 39-57.

Жарких В. Ю. Прагматизм і сучасна філософська традиція. Мультиверсум. Філософський альманах: Збірник наукових праць. К., 2009. Вип. 77. С. 79-88.

Пирс Ч.С. Закрепление верования. Вопросы философии. 1996. № 12. С. 113-114.

Пирс Ч.С. Как сделать наши идеи ясными. Вопросы философии. 1996. № 12. С. 120-132.

АНДРЕЙ ОСИПЦОВ

доктор педагогических наук, профессор заведующий кафедрой физического воспитания, спорта и здоровья человека, Мариупольский государственный университет (г.Мариуполь, Украина) e-mail: a.osiptsov@mdu.in.ua,ORCID 0000-0002-1640-2632

ОЛЬГА ЦЫБУЛЬКО кандидат исторических наук, доцент кафедры философии и соичологии, Мариупольский государственный университет (г.Мариуполь, Украина) e-mail: ostsybulco@ukr.net, ORCID 0000-0003-1297-5465

НАТАЛИЯ САЛЬНИКОВА кандидат исторических наук, заведующая кафедры гуманитарных дисциилин, Донеиякий юридический институт МВД Украинь (г.Мариуполь, Украина) ORCID 0000-0003-4931-0491

\section{ПРОБЛЕМА РАЗВИТИЯ ОБРАЗОВАТЕЛЬНЫХ УБЕЖДЕНИЙ В ФИЛОСОФСКОЙ ТРАДИЦИИ ЧАРЛЬЗА ПИРСА}

В статье исследуется проблема развития образовательных убеждений в философской традиции Чарльза Пирса. Пирс поддерживает позицию, которая требует систематического исследования и фундаментальной открытости новым идеям. Это требует посредничества между дисциплинированными индукцией и дедукцией, с одной стороны, и эстетически созерцательной, интуитивной и свободной игры с идеями, с другой, поскольку убеждения приобретают определенную форму и развиваются в рамках динамического взаимодействия между непрерывными процессами в научном коллективе. Если же мы хотим применить взгляды Пирса в отношении социального построения образовательных убеждений, то мы сразу же обнаружим, что наши верования не отделены от фактически основанных на нормах образования и взаимодействуют с ними. Пирс способствует пониманию образовательных убеждений как «живого исторического существа» и «здравого смысла». Однако, поскольку образовательные убеждения косвенные, социально ориентированные и ориентированны на будущее, мы не можем судить об образовательных убеждения основываясь на предварительных выводах. Поскольку образовательные убеждения обязательно являются предварительными и не окончательными. Образовательные убеждения и суждения должны оцениваться в соответствии с легитимностью норм исследования, то есть норм, которые 
направляют образовательные исследования, способствуют построению теории и практики.Таким образом, принимая точку зрения Пирса, исследования в области образования, построения теории и практики должны характеризоваться как взаимодействие общих процессов совместного обучения. При этом метод исследования Пирса - как этос образовательного исследования, построения теории и практики - может быть полезен для отличия догматизма от прагматизма.

Ключевые слова: прагматизм; образовательные убеждения; образование; значение; практика

ANDREY OSIPTSOV

Doctor of Pedagogical sciences, Professor, Director of the Department of physical education, sport and human health, Mariupol State University (Mariupol, Ukraine) e-mail:a.osiptsov@mdu.in.ua,ORCID 0000-0002-1640-2632

OLGA TSYBULKO Phd in History, Associate Professor, Department of Philosophy and Sociology, Mariupol State University (Mariupol, Ukraine) e-mail: ostsybulco@ukr.net,ORCID 0000-0003-1297-5465

NATALIIA SALNIKOVA PhD in History, Head of the Humanities Department, Donetsk Law Institute of the Ministry of Internal Affairs of Ukraine (Mariupol, Ukraine) ORCID 0000-0003-4931-0491

\section{PROBLEM OF DEVELOPMENT OF EDUCATIONAL BELIEFS IN PHILOSOPHICAL TRADITION OF CHARLES PIERCE}

The article examines the problem of the development of educational beliefs in the philosophical tradition of Charles Pierce. Pierce maintains a position that requires systematic research and fundamental openness to new ideas. This requires mediation between disciplined induction and deduction, on the one hand, and aesthetically contemplative, intuitive, and free game of ideas, on the other, since clear beliefs acquire a certain form and develop within the framework of the dynamic interaction between continuous and fragmentary processes in the research team. If we want to apply Pierce's views to the social construction of educational beliefs, then we will immediately discover that our beliefs are not separated from the actual norms of education and interact with them. Pierce contributes to the understanding of educational beliefs as «living historical creature» and «common sense». However, since educational beliefs are mediated, socially oriented and oriented towards the future, we can not judge educational beliefs based on previous conclusions. Because educational beliefs are necessarily preliminary and not final. Educational beliefs and judgments should be evaluated in accordance with the legitimacy of the norms that guide research, that is, the norms that guide educational research, the construction of theory and practice. Thus, taking Pierce's point of view, research in education, the construction of theory and practice should be characterized as the interaction of common processes of joint learning. At the same time, the method of research of Pierce - as an ethos of educational research, the construction of theory and practice - may be useful for the difference between dogmatism and pragmatism. Setting a task and analyzing recent publications. The modern Ukrainian educational system is not without problems and disadvantages. Particularly relevant today is the understanding the essence of such a phenomenon as the «educational process». In this context, it is logical to attempt an analysis of the philosophical heritage of the prominent pragmatist Charles Pierce. Presenting main material. The article examines the problem of the development of educational beliefs in the philosophical 
tradition of Charles Pierce. Pierce describes cognition as a relational and evolutionary phenomenon, which is also a product of our thinking, that is, our beliefs, without a doubt, should be understood as a relational and evolutionary factor. In the epistemological essay «Some Effects of Four Inabilities» Pierce expands this argument by arguing that thinking itself is completely devoid of value. Consequently, educational beliefs should be understood as relational, evolutionary, because persuasions interact continuously with other ideas, as they are included in the personal and intellectual biography of the teacher. Educational beliefs are socially oriented, that is, educational beliefs are an integral part of socially substantiated discourses. This is what Pierce is considering when he states that «the social principle emanates from logic». This «social principle» is connected with the concept of Pearce about the final consensus and the reasons for this is the characterization of scientific logic as a «critical common sense». According to Pierce's views, the final consensus, or «ultimate thought», should be seen as a regulatory ideal for scientific practice, since the truth is what an unlimited number of people will reach if it continually explores this hypothesis. Therefore, the reason Pierce rejected the subjective criterion for evidence is based on the rejection of biased materialism and the historical fact that stubborn people often adhere to false beliefs and the fact that such knowledge may be related to the a priori concept. On the contrary, Pierce argues that knowledge should be regarded as a socially tuned, a posteriori phenomenon. Therefore, Pierce explains how educational beliefs are oriented towards the future, since they are continuously constructed, reconstructed and become traditional in connection with reflections on the goals and extent of educational processes. That is, our convictions are based on and confirmed by practical considerations related to educational processes, in the sense that our beliefs are principles upon which we are ready to live. In this context, educational convictions become meaningful depending on expectations, and what contribution they can make to the development of an educational project. Consequently, educational convictions are not only based on past beliefs, but can also be characterized as focused on future «principles of hope». And Pierce emphasizes how educational convictions are built into the social creation of meaning. Conclusions. Pierce maintains a position that requires systematic research and fundamental openness to new ideas. This requires mediation between disciplined induction and deduction, on the one hand, and aesthetically contemplative, intuitive, and free game of ideas, on the other, since clear beliefs acquire a certain form and develop within the framework of the dynamic interaction between continuous and fragmentary processes in the research team. If we want to apply Pierce's views to the social construction of educational beliefs, then we will immediately discover that our beliefs are not separated from the actual norms of education and interact with them. Pierce contributes to the understanding of educational beliefs as «living historical creature» and «common sense». However, since educational beliefs are mediated, socially oriented and oriented towards the future, we can not judge educational beliefs based on previous conclusions. Because educational beliefs are necessarily preliminary and not final. Educational beliefs and judgments should be evaluated in accordance with the legitimacy of the norms that guide research, that is, the norms that guide educational research, the construction of theory and practice. Thus, taking Pierce's point of view, research in education, the construction of theory and practice should be characterized as the interaction of common processes of joint learning. At the same time, the method of research of Pierce - as an ethos of educational research, the construction of theory and practice - may be useful for the difference between dogmatism and pragmatism.

Key words: pragmatism; educational beliefs; education; meaning; practice

\section{REFERENCES}

Deledalle G. (2000) Charles Peirce's Philosophy of Signs: Essays in Comparative Semiotics, Bloomington: Indiana University Press. 372 p. Rettieved from http://www.southernsemioticreview.net/review-of-deledalle-by-geoffrey-sykes/) (In English). 
Peirce C.S. (1992) The Essential Peirce: Selected Philosophical Writings, vol. 1 (1867-1893), ed. N. Houser and C. Kloesel, Bloomington: Indiana University Press. 567 p. (In English).

Peirce C.S. (1998) The Essential Peirce: Selected Philosophical Writings, vol 2 (1893-1913), ed. the Peirce Edition Project, Bloomington: Indiana University Press. 621 p. Rettieved from https://altexploit. files.wordpress.com/2017/11/charles-s-peirce-nathan-houser-christian-jw-kloesel-peirce-edition-project-peirce-edition-project-the-essential-peirce -selectedphilosophical-writings-volume-2 -1893-1913-india.pdf (In English).

Schurz G. (1998) Kinds of Pragmatisms and Pragmatic Components of Knowledge. The Role of Pragmatics in Contemporary Philosophy. Vienna. Rettieved from https://www.academia.edu/19417228/Kinds_of_Pragmatisms_and_Pragmatic_Component s of Knowledge Author (In English).

Zharkih V.Yu. (2009) Pragmatizm i suchasna filosofska traditsiya / V.Yu. Zharkih // Multiversum. Filosofskiy almanah: Zbirnik naukovih prats. K.Vip. 77. S. 79-88. (In Ukraine).

Pirs Ch.S. (1996) Zakreplenie verovaniya // Voprosyi filosofii. № 12. S. 113-114. (In Russian).

Pirs Ch.S. (1996) Kak sdelat nashi idei yasnyimi // Voprosyi filosofii. № 12. S. 120-132. (In Russian).

Надійшла до редакції 27.05.2019 